\title{
Notes on the Distribution of the Pteridophytes of Suriname
}

\author{
K. U. KRAMER*
}

In a forthcoming publication (Kramer, in prep.) floristic and taxonomic data of the pteridophyte flora of Suriname will be assembled, with keys and notes on their local distribution and ecological preference. The present paper deals with the geographical distribution of Suriname pteridophytes beyond the boundaries of Suriname (Fig. 2), a subject that lies beyond the scope of a local fern Flora.

In the past, some (but relatively not very many) authors of fern Floras included a paragraph on the distribution of the taxa (Posthumus, 1928; Christensen, 1932; Backer \& Posthumus, 1939). In some other fern Floras some space is devoted to ecology, but very little to geography (Holttum, 1954). In still others, considerations of a general kind on ecology and geography are altogether lacking (Vareschi, 1969). Lyell (1870), in his rather little-known book on the distribution of ferns, tried to bring together all the data known at his time; his work is now, of course, almost exclusively of historical significance.

As far as pteridophytes are concerned, there is in Suriname virtually but a single environment - the forest-and as a whole our data on fern distribution are too scanty to differentiate between the various types of forest, as was done, for example, by Brownlie (1973) for the species of Lindsaea in Fiji. It is my impression, however, that in the future a number of fern species will prove to be indicators of certain forest types in Suriname, too. Ferns occurring exclusively on savannas are very few in number (mainly a few species of Schizaea). The same is true for ferns confined to rocks, like Doryopteris conformis Kramer \& Tryon and Pterozonium paraphysatum (A. C. Smith) Lellinger; most epilithic species also grow frequently on tree bases or forest soil. The ferns preferring swamps and open water are equally few in number and are as a rule widespread.

The principal ecological categories which can be distinguished in the Suriname pteridophytes are epiphytes and terrestrial species. On rocks and shaded, mossy tree bases the two groups may meet, but by and large they are fairly sharply delimited. Therefore, I differentiate between epiphytes and terrestrial species by considering as epiphytes only pteridophytes that are completely or nearly confined to an epiphytic habitat. This excludes, among others, a number of Asplenium species often regarded as epiphytes, but which, in my experience, quite often are found on rocks, decaying wood on the forest floor, etc. Compare Morton and Lellinger (1966), where epiphytism in Asplenium is actually used as a key character, to which various objections may be raised.

There are, of course, pteridophytes that occur only in the "sub-cloud forests," which are montane forests that approach cloud forests on the loftiest chains and peaks in the center of Suriname. But in many cases it is very difficult to ascertain whether the species truly are confined to montane forests or have only been collected there more often. For instance, recently I found Cyathea macrocarpa (Presl) Domin and Lindsaea parkeri (Hooker) Kuhn near Zanderij in the lowland

*Institute of Systematic Botany, University of Utrecht, Netherlands. Current address: Institut für Systematische Botanik der Universität Zürich, Switzerland. 

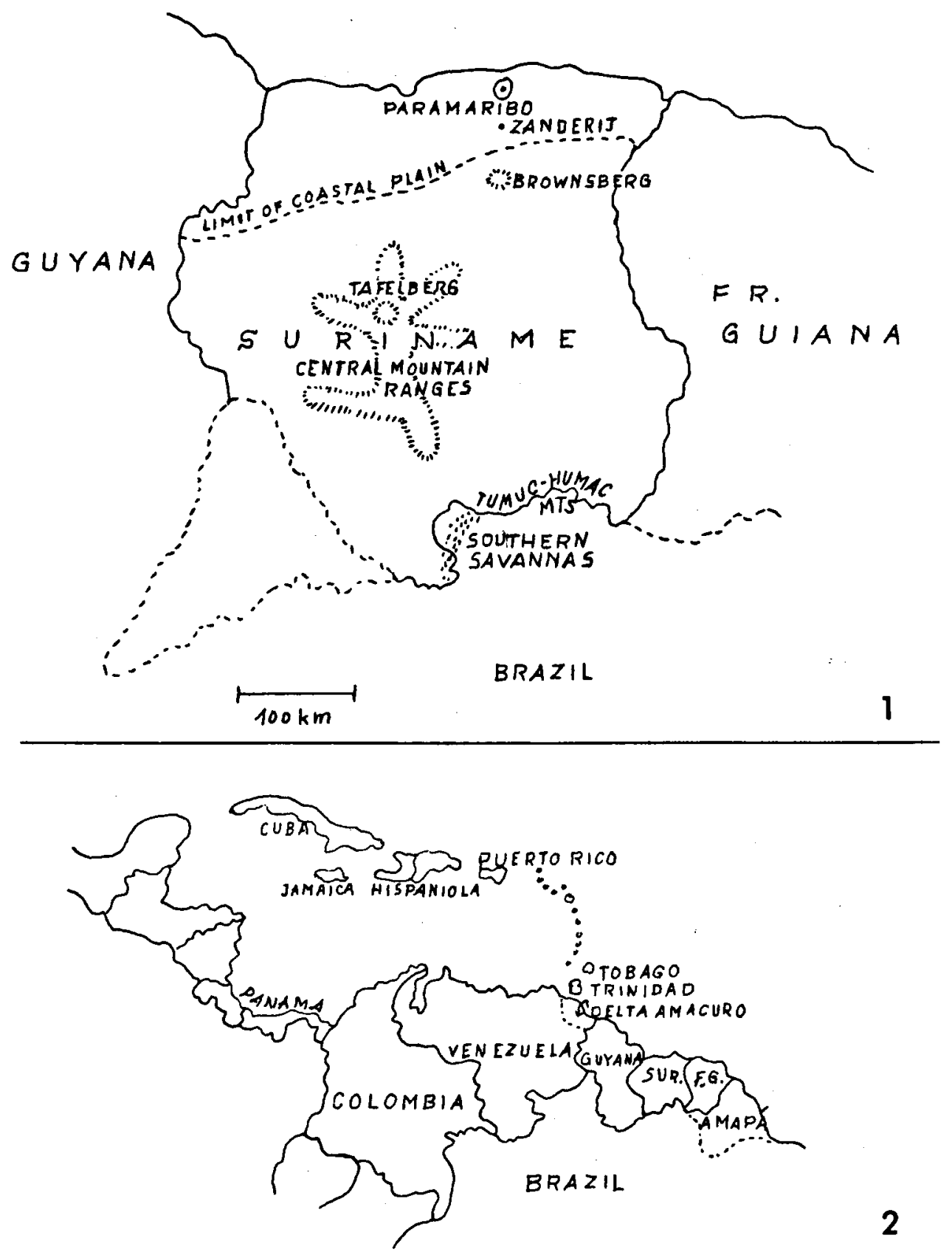

FIG. 1. Map of Suriname. FIG. 2. Map of northern South America and adjacent regions. 
on the edge of the coastal plain (Fig. I). These species otherwise are regarded as typical of the hills and mountains, or at least typical of the interior. The most likely category of species truly confined to the interior are those found on Roraima sandstone substrate and soils derived from it and which occur only in a limited area in the center of Suriname, e.g., Pterozonium paraphysatum (A. C. Smith) Lellinger, Lindsaea pendula Klotzsch, and L. stricta (Swartz) Dryand. var. jamesoniiformis Kramer. But even some of these may turn up in lowland savanna areas, as exemplified by Lycopodium duidae A. C. Smith var. guianense Kramer, one of the characteristic species of the Kappel Savanna on Roraima substrate at the foot of Tafelberg (Kramer \& van Donselaar, 1968), but again known from one find near Zanderij. I think that only in the case of epiphytes of the "sub-cloud forest" may we be reasonably sure that they do not occur outside this vegetation type.

Very little can be said about geographical limits of species within the country, other than those of altitude and other ecological factors. For example, species found only in the west or south are as a rule known by so few collections that it would be highly speculative to draw conclusions from their presently known stations. ${ }^{1}$ We probably may make an exception for the southern savannas, which straddle the Tumuc-Humac Mountains on the southern border of Suriname. A considerable number of angiosperms have their only (usually northernmost or easternmost) station in Suriname in this area, and the same may be true for some of the pteridophytes known in the country from this area alone: Anemia ferruginea H. B. K. var. ahenobarba (Christ) Mickel, A. pastinacaria Moritz ex Prantl, and Doryopteris collina (Raddi) J. Smith.

For conclusions of a general nature, we should thus focus our attention on the complete distribution of the species. I have tried to divide them into a number of groups representing certain distribution types, as was done by van Donselaar for savanna plants $(1965$, p. $75 \mathrm{ff})$. I realize that this is not without risk in ferns, as their taxonomy in many cases is insufficiently understood and their areas often are not reliably known. Nevertheless, the figures may give some general impression of the phytogeographic ties of the fern flora of Suriname. For recent studies of a similar kind of fern floras of other areas, see Holttum (1964), Brownlie (1965), and Iwatsuki $(1972,1973)$. The number of comparable papers is, as far as known to me, quite small.

The figures may soon become outdated as further exploration adds more species to the list and as further study shows taxa here accepted as species to be aggregates. Posthumus's geographical account in his fern Flora of the Guianas (1928, pp. 173-185) is now almost entirely outdated.

What the figures do not tell us is how common the species are in Suriname, i.e., what part they play in the actual composition of the plant cover. According to my own impressions in the field, the fern flora of the rain forest floor is very strongly dominated by a small number of species: Adiantum latifolium Lam., A. obliquum Willd., $A$. cajennense Willd. ex Klotzsch, $A$. terminatum Kunze ex Miquel,

${ }^{1}$ Schizaea incurvata Schkuhr, common on savannas in the north, so far has not been found in eastern Suriname nor in French Guiana. 
Lindsaea lancea (L.) Bedd., L. guianensis (Aubl.) Dryand., L. dubia Spreng., Trichomanes pinnatum Hedw., T. cristatum Kaulf. ex Poir., T. vittaria DC. ex Poir., and Ctenitis protensa (Afz.) Ching. Most other species are very much rarer. For the casual botanical observer, Suriname gives the impression of being the land of Adiantum and Lindsaea. The dominating epiphytes cannot be enumerated so readily, as it is difficult to obtain a true and complete picture of these rather inaccessible plants. In the lowland apparently seyeral species of Polypodium subgenus (or genus) Microgramma predominate: $P$. ciliatum Willd., $\boldsymbol{P}$. lycopodioides L., $\boldsymbol{P}$. persicariifolium Schrad., as well as $\boldsymbol{P}$. aureum L., $\boldsymbol{P}$. percussum Cav., $\boldsymbol{P}$. crassifolium L., and $\boldsymbol{P}$. phyllitidis L. Other common epiphytes of this area are Trichomanes pedicellatum Desv., T. ankersii Parker ex Hook. \& Grev. (these two perhaps more correctly called scandent hemiepiphytes), Vittaria lineata (L.) J. E. Smith, Dicranoglossum desvauxii (Klotzsch) Proctor, Asplenium serratum L., Antrophyum guayanense Hieron., and Hymenophyllum polyanthos (Swartz) Swartz. In the hills and mountains other species join or replace them, like Xiphopteris serrulata (Swartz) Kaulf., Hecistopteris pumila (Spreng.) J. Smith, and Hymenophyllum hirsutum Swartz.

Another point is the unexpected, apparent great rarity or even complete absence of some tropical American ferns which are otherwise widespread and often common elsewhere. Examples of locally rare, generally widespread species are: Adiantum macrophyllum Swartz, Anemia phyllitidis (L.) Swartz, Blechnum occidentale L., Cyclopeltis semicordata (Swartz) J. Smith, Dennstaedtia obtusifolia (Willd.) Moore, Doryopteris pedata (L.) Fée, Hemidictyum marginatum (L.) Presl, Hypolepis repens (L.) Presl, Trichomanes polypodioides L., and T. hymenophylloides v.d. Bosch. Most of these are known from only a single collection or a single locality.

Ferns that might be expected in Suriname because of their overall distribution but that have never been found so far include Gleichenia bifida (Willd.) Spreng., Peltapteris peltata (Swartz) Morton, Polybotrya osmundacea Humb. \& Bonpl. ex Willd., Polypodium fraxinifolium Jacq., P. lanceolatum L., and Pteris denticulata Swartz.

\section{DISTRIBUTION TYPES}

The distribution of 286 species of pteridophytes occurring (or strongly suspected to occur) in Suriname seems to be at present sufficiently known. These may be divided into distribution types as follows. I have consciously avoided the term "flora element," as it is too much subject to ambiguous interpretation. For a discussion, see van Balgooy (1971, pp. 58-59). The distributions of the pteridophytes of Suriname discussed below are summarized in Table 1 .

1. Pantropic Species.-These often extend far into subtropical areas, particularly in the south. This category includes 13 species (4.5\% of the fern flora). Examples are: Acrostichum aureum L., Ceratopteris thalictroides (L.) Brongn., Didymochlaena truncatula (Swartz) J. Smith, Psilotum nudum (L.) Pal. Beauv., and Thelypteris interrupta (Willd.) K. Iwats. $[=T$. totta (Thunb.) Schelpe $=T$. gongylodes (Schkuhr) St. John in Small]. Some examples are probably taxonomic 
aggregates, like Hymenophyllum polyanthos (Swartz) Swartz. Many, but by no means all, of these ferns are frequent to common in Suriname. Examples of locally rare species are the Psilotum and also Cheiroglossa palmata (L.) Presl.

2. Tropical American-Tropical African Species.-These are all widespread in tropical America, and the same holds for Suriname. There are two certain examples $(0.7 \%)$ of this distribution type: Thelypteris quadrangularis (Fée) Schelpe (see A. R. Smith, 1971) and Xiphopteris serrulata (Swartz) Kaulf. Two more possible examples (another 0.7\%) are: Pityrogramma calomelanos (L.) Link, which perhaps is native in Africa, and Trichomanes rigidum Swartz, which is regarded by some modern authors (Taton, 1946; Schelpe, 1970) as conspecific with the African $T$. cupressoides Desv. Most examples of this distribution type recorded in the older literature have proved to be incorrect, like Polypodium polypodioides (L.) Watt and Trichomanes krausii Hook. \& Grev.; the African plants are now assigned to other species.

TABLE 1. NUMBER AND PERCENTAGE OF SURINAME PTERIDOPHYTES ACCORDING TO DISTRIBUTION TYPE.

Distribution type

1. Pantropic

2. Tropical American-Tropical African

3. Tropical American-Tropical Asiatic

4. Neotropic-wide

5. Tropical Continental American

6. Tropical (and Subtropical) South American

7. Northern South American

8. Circum-caribbean

9. Northern South American-Lesser Antillean

10. Guianan-wide Endemic

11. Restricted Guianan Endemic

12. Anomalous

13. Alien

\begin{tabular}{c} 
Number \\
13 \\
$2+2 ?$ \\
2 \\
104 \\
19 \\
23 \\
56 \\
23 \\
12 \\
7 \\
8 \\
12 \\
3 \\
\hline 286
\end{tabular}

3. Tropical American-Tropical Asiatic Species.-Some of these extend to tropical Australia. There are two examples $(0.7 \%)$ in Suriname: Blechnum serrulatum L. C. Rich. and Pteridium aquilinum (L.) Kuhn subsp. caudatum (L.) Bonap. Both are terrestrial species of open habitats.

4. Neotropic-wide Species.-These occur almost throughout tropical America, except for the driest and loftiest parts, and in many cases extend to Florida, subtropical Brazil, Argentina, etc. This is by far the largest group, and includes $104(36.5 \%)$ species. Slightly over a third of these are epiphytes, a figure that comes very close to the proportion of epiphytes in the Suriname pteridophyte flora as a whole. Examples can be gleaned from the forthcoming Flora.

This group may actually be too large. Some species may have been too broadly circumscribed and may eventually be shown to consist of several smaller, less widespread species, as Evans (1969) has demonstrated for Polypodium pectinatum L. sensu latissimo.

There seems to be little correlation between the size of the area of a species and its frequency in Suriname. Some neotropic-wide species are very common, like 
Adiantum latifolium Lam. and Ctenitis protensa (Afz.) Ching. But others, like Cyclopeltis semicordata (Swartz) J. Smith and Doryopteris pedata (L.) Fée, are quite rare.

5. Tropical Continental American Species.-A few of these species extend to Cuba and/or to Jamaica, islands known to have a fair share of otherwise continental neotropical species. Trinidad is here regarded as part of the continent, for geological and general biogeographical reasons.

Nineteen species (6.7\%) exhibit this kind of distribution, in my opinion a surprisingly low figure. Examples are: Adiantum humile Kunze, Lindsaea divaricata Klotzsch, Metaxya rostrata (H.B.K.) Presl, Polypodium percussum Cav., Selaginella flagellata Spring, and Trichomanes botryoides Kaulf. Only three or four of the group are epiphytes.

6. Tropical (and Subtropical) South American Species.-Some of these extend to Panama, and many to Trinidad. There are 23 species (8\%) in this group. Examples are: Adiantum dolosum Kunze, Anemia villosa Humb. \& Bonpl. ex Willd., Dicranoglossum desvauxii (Klotzsch) Proctor, Oleandra pilosa Hooker, Polypodium (Microgramma) persicariifolium Schrad., P. decumanum Willd., Selaginella radiata (Aubl.) Spring, and Thelypteris hostmannii (Klotzsch) Morton. Nine are epiphytes.

7. Northern South American Species.-These sometimes extend into Panama and/or Trinidad. Most occur only in the Guianas from Amapa westward and range to Venezuela and eastern Colombia, but several extend to Amazonian Peru and/or Brazil, approximately to the Amazon River. This is a large group of 56 species (19.7\%). Surprisingly, only seven epiphytes show this type of distribution. Typical examples of terrestrial species include Adiantum leprieurii Hooker, Ctenitis refulgens (Klotzsch) Vareschi, Doryopteris conformis Kramer \& Tryon, Lindsaea parkeri (Hooker) Kuhn, Lycopodium duidae A. C. Smith, Selaginella parkeri (Hook. \& Grev.) Spring, Thelypteris macrophylla (Kunze) Morton, and Trichomanes cellulosum Klotzsch. Examples of epiphytic species are: Elaphoglossum laminarioides (Bory) Moore, Grammitis furcata Hook. \& Grev., Trichomanes pinnatinervium Jenm., and Xiphopteris nana (Fée) Copel. The latter is reported to extend to Mato Grosso, Brazil.

8. Circum-caribbean Species.-This designation is not entirely correct, as the species extend, of course, far to the east of the Caribbean Sea into the Guianas. Under this heading I have assembled the species occurring in the West Indies (and more or less throughout them), Central America, and northern South America from Colombia to Suriname, French Guiana, or Amapá. A few extend south to Peru or north to the southeastern United States; others have only been recorded from some scattered localities in the area and perhaps will eventually prove to have a more continuous distribution pattern.

This is an interesting distribution type, of which I have found few examples in recent literature. Van Donselaar (1965, p. $75 \mathrm{ff}$, table 11) made an analysis of the distribution of savanna plants in Suriname. He did not explicitly distinguish a circum-caribbean element, but his table includes some instances of this distribution type: Montrichardia arborescens (L.) Schott (Araceae), Heliotropium 
fruticosum L. (Boraginaceae), and Rhynchospora curvula Griseb. (Cyperaceae). Thomas's map (1960, p. 79) of Cyrilla racemiflora L., when supplemented by some finds in Suriname, comes close to this distribution type. Tryon (1972) analyzed the concentration of endemic ferns in the neotropics, distinguishing centers of endemism and floristic connections between them, but did not come across this particular distribution pattern.

There are no fewer than 23 pteridophytes (8\%) in this category; perhaps a few of these have insufficiently known distributions that extend further, and so do not really belong here. It seems highly significant that 15 of the species are epiphytes, and that the great majority of the species occur in Suriname only in the hills and mountains. Two Guianan Gesneriaceae have this distribution type: Chrysothemis pulchella (Donn ex Sims) Dcne. and Columnea scandens L. (Leeuwenberg, 1958, map 1), but only the latter is an epiphyte. I should be grateful to have further examples of pteridophytes or other plants brought to my attention. The circumcaribbean distribution type must have a paleogeographical-ecological basis. What is so striking about it is that the species do not extend all the way south along the Andes to Bolivia and in the Brazilian coastal ranges to southeastern Brazil, as a good many other species do.

Examples of circum-caribbean pteridophytes in Suriname are Ceratopteris deltoidea Bened., Cochlidium linearifolium (Desv.) Maxon in C. Chr., Hymenophyllum lanatum Fée, Polystichopsis ochropteroides (Baker) Morton, Polypodium dissimile L., Thelypteris decussata (L.) Proctor, Antrophyum feei Schaffner ex Fée, Ctenopteris melanosticta (Kunze) Copel., and Lycopodium wilsonii Underw. \& Lloyd. The last two species seem to be known only from a few scattered localities, but apparently fall into this category.

9. Northern South American-Lesser Antillean Species.-These also may extend to Puerto Rico or Hispaniola, but are absent from Cuba, Jamaica, and Central America (except for Panama in some cases). Therefore, these species cannot be called circum-caribbean. I have found 12 examples (4.2\%) of this distribution type in Suriname, four of them epiphytes. Among them are: Adiantum phyllitidis $\mathbf{J}$. Smith, Cyathea (Nephelea) imrayana Hooker, Elaphoglossum pteropus C. Chr., Lindsaea guianensis (Aubl.) Dryand. subsp. guianensis, Ormoloma imrayanum (Hooker) Maxon, which has not yet been recorded from Suriname but which is known from both French Guiana and Guyana (formerly British Guiana), Thelypteris glandulosa (Desv.) Proctor, and Trichomanes pedicellatum Desv.

10. Guianan-wide Endemic Species.-These are not strictly confined to the Guianas, but often range south and east to the territory of Amapá, Brazil, and northwest to the territory of Delta Amacuro, Venezuela, and to Trinidad. Considering that Tryon (1972) treated the Guianas as a secondary center of fern endemism, this group is surprisingly weak in Suriname, but he delimited the area more broadly than is done in the present study. Seven species $(2.3 \%)$, two of them epiphytes, are included in this group. According to Tryon, the Roraima sandstone substrate is important for the occurrence of Guianan endemics. This substrate is very limited in Suriname, and consequently the species occurring on it are neither widespread nor richly represented in the country. The Guianan endemics of 
Suriname enumerated below actually are not at all sandstone species. I should like to emphasize that species representative of the sandstone flora, like Lindsaea pendula Klotzsch, occur in the whole Roraima sandstone area from Suriname to southeastern Colombia, and are here classified as species of northern South America (group 7), not as Guianan-wide endemic species. The species of this group are: Adiantum adiantoides (J. Smith) C. Chr., Cyathea boryana (Kuhn) Domin, Danaea trifoliata Reichenb. in Kunze, D. simplicifolia Rudge, Elaphoglossum luridum (Fée) Christ, Stigmatopteris varians (Fée) Alston, and Thelypteris guyanensis (Fée) Morton. I would like to be informed whether any of these species occur in other areas, unknown to me.

11. Restricted Guianan Endemic Species.-The Guianan area is defined as for group 10. With more complete data, the subgroups herein may prove to coincide, or at least to blend with one another. The eight species $(2.8 \%)$ in this category may be grouped as follows.

a. Suriname and French Guiana (and Amapá): Trichomanes mougeotii v. d. Bosch and Ctenopteris kegeliana (Kunze) Kramer. ${ }^{2}$

b. Suriname and Guyana: Cyathea (Sphaeropteris) marginalis (Klotzsch) Domin.

c. Suriname only: Adiantum tripteris Kramer, Ctenopteris staheliana (Posth.) Kramer, ${ }^{3}$ Notholaena solitaria R. M. Tryon, Selaginella caudorrhiza Baker, and Thelypteris holodictya Kramer. Because the taxonomic status of Ctenopteris staheliana and Selaginella caudorrhiza is open to some doubt and because the other species have all been found only once and therefore hardly anything is known about their distribution, we certainly may not call Suriname a center of fern endemism.

12. Anomalous Species.-These have unusual distribution types, at least as far as ferns are concerned, and hardly are suitable for qualitative evaluation. Again, further exploration may show some of them to have other, more usual distribution patterns. Others will, however, probably remain "anomalously" distributed, as is found occasionally in phytogeography (see van Balgooy, 1971, pp. 71-73). The 12 species (4.2\%) may be grouped as follows.

a. Suriname and low-lying areas along the coast of eastern and southeastern Brazil: Elaphoglossum strictum (Raddi) Moore.

b. Northern South America-southern Brazil disjuncts: Doryopteris sagittifolia (Raddi) J. Smith, D. collina (Raddi) J. Smith, and Stigmatopteris rotundata (Willd.) C. Chr. This type of distribution occurs in several Doryopteris species and was discussed by Tryon (1944). Examples among angiosperms also exist: Habenaria platydactyla Kraenzl. (Orchidaceae) and Psidium grandifolium Mart. (Myrtaceae).

c. Central and northern or northwestern South America, but not extending throughout Central America (including southeastern Mexico) and tropical South America. This distribution is a fragment of group 5. The species that have this

${ }^{2}$ Ctenopteris kegeliana (Kunze) Kramer, comb. nov. Basionym: Polypodium kegelianum Kunze, Linnaea 21: 210.1848.

${ }^{3}$ Ctenopteris staheliana (Posth.) Kramer, comb. nov. Basionym: Polypodium stahelianum Posth., Rec. Trav. Bot. Néerl. 23: 401, f. 2. 1927. 
type of distribution are: Diplazium lechleri (Mett.) Moore, Polypodium adnatum Kunze, $P$. flagellare Christ, and Trichomanes tuerckheimii Christ. In connection with what was said under group 8 , it may be significant that all these species except the Diplazium are epiphytes.

d. West Indian and tropical South American species apparently lacking in Central America. None of these are epiphytes: Lomagramma guianensis (Aubl.) Ching, Pteris deflexa Link, and Tectaria trifoliata (L.) Cav.

13. Alien Species.-As is the rule in pteridophytes, these are very few in number. The three species (1\%) are all paleotropical or paleosubtropical in origin: Pteris vittata L., P. tripartita L., and Thelypteris opulenta (Kaulf.) Fosb. Because $P$. tripartita has been found in the deep south of Suriname and because I have also seen a specimen from French Guiana collected about 140 years ago, I think this species may be native but locally very rare in South America, as the preponderantly Asiatic fern Lindsaea ensifolia Swartz is in tropical Africa.

It may be noted in passing that out of 13 species of Selaginella found in Suriname, one is distributed over tropical Central and tropical South America, three over tropical South America, and eight occur only in northern South America. The doubtfully endemic $S$. caudorrhiza Baker is referred to above. It must certainly be significant that in this genus, with its much heavier spores, there are on the one hand no very widely distributed species, but on the other hand hardly any very narrowly distributed ones, although such species certainly exist in other areas. Curiously, many species extend throughout the Lesser Antilles (Alston, 1952), but none of the Guianan species reaches these islands, nor vice-versa.

\section{RELATIONSHIPS AND HISTORY OF THE SURINAME PTERDIOPHYTE FLORA}

In the older literature (e.g., Christ, 1910, pp. 301-303) and more recently, in papers dealing mainly with forest trees and their distribution, the flora of the Guianas often is treated as an appendix, as an offshoot of the flora of Amazonian Brazil. This seems unlikely on geological-paleogeographical grounds, and it is not at all true for an old group like the ferns, as shown above.

Another matter to be taken into account is the assumption of some authors that most of the forest cover of Suriname and larger adjacent parts of northern South America is of quite recent origin. On palynological grounds, van der Hammen (1972) showed that the cool periods of the Pleistocene were considerably drier in the area under consideration and that savannas, savanna woods, and the like were more extensive in that period than they are now. Haffer (1969) reconstructed forest refugia and corridors of migration for dry environment species, chiefly on ornithological evidence. Hoogmoed (1973) went further, stating: ". . We may assume that about 3000 years ago the greater part of Suriname was covered with savannahs and that only the Tumuc Humac and Boundary Mountains were covered with rain-forest. . . After this dry period the forest again spread over Surinam starting from the Tumac Humac and Boundary Mountains." Ferns probably are not the best indicators of such developments in the past, and the distribution of savanna species may be much more readily explained by assumptions like Haffer's. It seems to me, however, that Hoogmoed's "deforestation" of 
virtually all of Suriname until about 3000 years ago goes too far. Today the forest flora is rich in both woody and herbaceous species in areas like Tafelberg, the Emma Range, and especially Brownsberg, a surprisingly rich hill situated not very far from the margin of the coastal plain and justly proclaimed a natural reserve (Bubberman et al., 1970).

I am indebted to Mr. F. Oldenburger for help with bibliographic data, to Dr. J. van Donselaar for the same and for helpful criticism of the manuscript, and to Dr. R. M. Tryon, Jr., for advice on the nomenclature of tree-ferns.

\section{LITERA TURE CITED}

ALSTON, A. H. G. 1952. A revision of the West Indian species of Selaginella. Bull. Brit. Mus. Bot. 1 (2): 27-47.

BACKER, C. A. and O. POSTHUMUS. 1939. Varenflora voor Java. 's Lands Plantentuin, Buitenzorg. xlvii $+370 \mathrm{pp}$.

BALGOOY, M. M. J. van 1971. Plant geography of the Pacific as based on a census of phanerogam genera. Blumea Suppl. 6: 1-222.

BROWNLIE, G. 1965. The geographical affinities of the South Pacific fern floras. Pacific Sci. 19: 219-223.

1973. The genus Lindsaea in Fiji. Amer. Fern J. 63: 91-98.

BUBBERMAN, F., et al. 1970. Brownsberg Natuurpark. Suralco Magazine 2: 3-19. Also published as Mededeling no. 1, Stichting Natuurbehoud Suriname [STINASU], Paramaribo.

CHR IST, H. 1910. Die Geographie der Farne. Gustav Fischer, Jena. 357 pp.

CHR ISTENSEN, C. 1932. The pteridophyta of Madagascar. Dansk Bot. Ark. 7: i-xv, 1-253, t. 1-80.

DONSELAAR, J. van 1965. An ecological and phytogeographic study of northern Surinam savannas. Wentia 14: 1-163.

EVANS, A. M. 1969. Interspecific relationships in the Polypodium pectinatum-plumula complex. Ann. Missouri Bot. Gard. 55: 193-293.

HAMMEN, T. van der 1972. Changes in vegetation and climate in the Amazon Basin and surrounding areas during the Pleistocene. Geologie en Mijnbouw 51: 641-643.

HAFFER, J. 1969. Speciation in Amazonian forest birds. Science 165: 131-137.

HOLTT UM, R. E. 1954. A Revised Flora of Malaya, vol. II. Ferns of Malaya. Gov't. Printing Off., Singapore. $643 \mathrm{pp}$.

1964. Distribution of some of the more primitive ferns of Mt. Kinabalu. Proc. Roy. Soc. London B, 161: 38-48.

HOOGMOED, M. S. 1973. Notes on the herpetofauna of Surinam II. W. Junk, The Hague. $419 \mathrm{pp}$.

IWATSUKI, K. 1972. Phytogeography of the pteridophytes in northem Thailand. Acta Phytotax. Geobot. 25: 69-78.

1973. Phytogeography of the pteridophytes in peninsular Thailand. Amer. Fern J. 63: 129-134.

KRAMER, K. U. and J. van DONSELAAR. 1968. A sketch of the vegetation and flora of the Kappel Savanna near Tafelberg, Suriname. Proc. Kon. Nederl. Akad. Wetensch. C, 71: 495-524.

LEEUWENBERG, A. J. M. 1958. The Gesneriaceae of Guiana. Acta Bot. Neerl. 7: 291-444.

LELLINGER, D. B. 1972. A revision of the fern genus Niphidium. Amer. Fern J. 62: 101-120.

LYELL, K. M. 1870. A geographical handbook of all the known ferns with tables to show their distribution. John Murray, London. $x+225 \mathrm{pp}$.

MORTON, C. V. and D. B. LELLINGER. 1966. The Polypodiaceae subfamily Asplenioideae in Venezuela. Mem. New York Bot. Gard. 15: 1-49.

POSTHUMUS, O. 1928. The ferns of Surinam and of French and British Guiana. Privately published at Malang, Java. $196 \mathrm{pp}$.

SCHELPE, E. A. C. L. E. 1970. Pteridophyta in A. W. Exell and E. Launert (eds.). Flora Zambesiaca. Crown Agents, London. 254 pp.

SMITH, A. R. 1971. Systematics of the neotropical species of Thelypteris section Cyclosorus. Univ. Calif. Publ. Bot. 59: 1-136. 
TATON, A. 1946. Révision des Hyménophyllacées du Congo Belge. Bull. Soc. Bot. Belg. 78: 5-42. THOMAS, J. L. 1960. A monographic study of the Cyrillaceae. Contr. Gray Herb. 186: 1-114. TRYON, R. M., Jr. 1944. Dynamic phytogeography of Doryopteris. Amer. J. Bot. 31: 470-473. 1972. Endemic areas and geographic speciation in tropical American ferns. Biotropica 4: $121-131$.

VARESCHI, V. 1969. Flora de Venezuela, vol. 1. Helechos. Instituto Botánico, Caracas. 1039 pp. 